\title{
PROFIL PEMECAHAN MASALAH SEGITIGA SISWA KELAS VIII SMP NEGERI 19 PALU DITINJAU DARI GAYA KOGNITIF
}

\author{
Indriani Sira $^{1)}$, Abd. Hamid ${ }^{2)}$, Evie Awuy ${ }^{3)}$ \\ indrysirabecks@gmail.com ${ }^{1)}$, hamid563@gmail.com ${ }^{2)}$,evieawuy1103@gmail.com ${ }^{3)}$
}

\begin{abstract}
Abstrak: Penelitian ini bertujuan untuk mendeskripsikan profil pemecahan masalah segitiga siswa kelas VIII SMP Negeri 19 Palu ditinjau dari gaya kognitif. Jenis penelitian ini adalah penelitian kualitatif. Hasil penelitian menunjukkan bahwa Hasil penelitian menunjukkan bahwa : 1) profil pemecahan masalah siswa FI pada tahap memahami masalah yaitu: mengidentifikasi informasiinformasi yang diketahui dan ditanyakan. 2) Profil pemecahan masalah siswa FI pada tahap membuat rencana yaitu: mampu membuat hubungan antara informasi yang ada dengan masalah yang ditanyakan dengan mengaikatkan pengetahuan dan pengalamannya. 3) Profil pemecahan masalah subjek FI pada tahap melaksanakan rencana yaitu subjek dengan gaya kognitif FI dapat menerapkan rencana yang telah dibuat selanjutnya melaksanakan rencana dengan menggunakan konsep yang telah dipelajari sebelumnya. 4) Profil pemecahan masalah siswa FI pada tahap memeriksa kembali yaitu: subjek memeriksa kembali langkah demi langkah hasil pekerjaan 5) Profil pemecahan masalah siswa FD pada tahap memahami masalah yaitu: dengan cara membaca masalah berulang-ulang dan membutuhkan waktu yang lebih lama dalam memahami masalah. 6) Profil pemecahan masalah siswa FD pada tahap membuat rencana yaitu: subjek kurang tepat dalam membuat rencana penyelesaian. $\quad 7)$ Profil pemecahan masalah subjek FD pada tahap melaksanakan rencana yaitu subjek mengalami kesulitan dalam menerapkan rencana yang telah dibuat sebelumnya sehingga menambahkan beberapa strategi untuk dapat menyelesaikan masalah yang dihadapi. 8) Profil pemecahan masalah siswa FD pada tahap memeriksa kembali yaitu: subjek tidak melakukan pengecekan kembali hasil pekerjaan.
\end{abstract}

Kata Kunci: Profil, Pemecahan Masalah, Segitiga, Gaya Kognitif.

Abstract: This study aims to describe the problem solving problem of triangle students of class VIII SMP Negeri 19 Palu in terms of cognitive style. This type of research is qualitative research. The results showed that the results showed that: 1) the problem solving profile of FI students at the understanding stage of the problem that is: identifying the information known and asked. 2) FI student problem-solving profile at the stage of making a plan that is: able to make the relationship between existing information with the problem that is asked by raising knowledge and experience. 3) Profile of FI subject problem solving at the stage of implementing the plan ie subjects with cognitive style FI can implement the plan that has been made subsequently implement the plan by using the concept that has been studied previously. 4) FI stuzdent problem-solving profile at reexamination stage: subject check back step by step job result 5) FD student problem solving profile at the understanding stage of the problem that is: by reading the problem repeatedly and takes longer time to understand the problem . 6) Profile of FD student problem solving at the stage of making a plan that is: the subject is less precise in making the settlement plan. 7) The problem solving profile of the FD subject at the stage of implementing the plan ie the subject has difficulty in applying the pre-made plan so as to add some strategies to solve the problems encountered. 8) FD student problem-solving profile at the re-examination stage ie: the subject does not re-check the work result.

\section{Keywords: Profile, Troubleshooting, Triangle, Cognitive Style}

Matapelajaran matematika perlu diberikan kepada semua peserta didik mulai dari sekolah dasar untuk membekali peserta didik dengan kemampuan berpikir logis, analitis, sistematis, kritis, dan kreatif, serta kemampuan bekerja sama. Untuk meningkatkan kemampuan memecahkan masalah perlu dikembangkan keterampilan memahami masalah, membuat model matematika, menyelesaikan masalah dan menafsirkan solusinya (Depdiknas, 
2006:9). Pemecahan masalah merupakan aktifitas atau usaha yang dilakukan oleh siswa untuk menyelesaikan suatu soal matematika yang tidak dapat diselesaikan dengan prosedur yang rutin.

Masalah matematika merupakan soal matematika yang diberikan kepada siswa, namun siswa tersebut tidak langsung dapat menyelesaikannya. Hudojo (2009) mengatakan bahwa terdapat dua syarat agar suatu pertanyaan merupakan masalah bagi siswa, yaitu: (1) pertanyaan tersebut merupakan tantangan bagi siswa tersebut untuk menjawabnya, (2) pertanyaan tersebut tidak dapat dijawab dengan prosedur rutin yang diketahui siswa.

Masalah matematika yang berhubungan dengan konsep-konsep matematika sering dijumpai dalam kehidupan sehari-hari. Adapun beberapa masalah yang berhubungan dengan konsep-konsep matematika satu diantaranya yaitu masalah matematika mengenai penerapan konsep geometri.

Geometri merupakan salah satu cabang matematika yang diajarkan mulai dari pendidikan dasar sampai pendidikan tinggi. Salah satu materi dalam geometri adalah bangun datar khususnya segitiga. Kondisi siswa dalam menyelesaikan masalah segitiga, selalu memiliki karakteristik dan kemampuan yang berbeda-beda.

Perbedaan-perbedaan karakter antar pribadi yang menetap dalam cara menyusun dan mengolah informasi serta pengalaman-pengalaman ini dikenal gaya kognitif. Gaya kognitif merupakan cara siswa yang khas dalam belajar, baik yang berkaitan dengan cara penerimaan dan pengolahan informasi, sikap terhadap informasi, maupun kebiasaan yang berhubungan dengan lingkungan belajar. Cara yang digunakan seseorang untuk mendapatkan pengetahuan dan cara seseorang dalam memproses informasi, merasakan, dan berperilaku dalam situasi belajar merupakan cara konsisten yang dilakukan oleh seseorang dalam proses pembelajaran (Slameto, 2003).

Menurut Abidin (2015) mengatakan bahwa terdapat dua pasang gaya kognitif penting yang sering diteliti dan dibahas dalam dunia pendidikan dan pembelajaran, yaitu: 1). Gaya kognitif yang didasarkan pada perbedaan secara psikologis yang meliputi gaya kognitif FI dan FD, dan 2). Gaya kognitif yang didasarkan pada perbedaan conceptual tempo, yang meliputi reflective dan impulsive.

Siswa dalam memecahkan masalah matematika memiliki cara yang berbeda-beda karena memiliki gaya kognitif yang berbeda-beda. Sebagaimana yang dikemukakan oleh Uno (Wisman, 2016) bahwa kemampuan seseorang untuk memahami dan menyerap pelajaran sudah pasti berbeda tingkatnya. Ada yang cepat, sedang, ada pula yang sangat lambat. Oleh karena itu, siswa seringkali melakukan hal yang berbeda dalam kegiatan pembelajaran agar bisa memahami sebuah informasi atau pelajaran yang sama.

Selanjutnya pentingnya suatu profil pemecahan masalah siswa ditinjau dari gaya kognitif karena seorang guru harus bisa memahami gaya kognitif siswanya selain itu dalam satu kelas setiap siswa memiliki gaya kognitif yang berbeda-beda sehingga dibutuhkan suatu rancangan pembelajaran yang sesuai dengan gaya kognitif siswa. Seperti yang dikemukakan oleh Joyce (Wisman, 2016) bahwa gaya kognitif merupakan salah satu variabel yang menjadi salah satu bahan pertimbangan dalam merancang pembelajaran.

Berdasarkan uraian tersebut, peneliti menyimpulkan bahwa perlu adanya suatu profil atau gambaran terhadap pemecahan masalah yang dilakukan oleh siswa sehingga guru dapat mengetahui letak dan jenis kesulitan matematika yang dilakukan siswa. Selanjutnya, guru dapat membuat strategi yang sesuai dengan gaya kognitif untuk mendorong siswa dalam memecahkan masalah matematika. Sehingga peneliti tertarik untuk melakukan penelitian yang berjudul "Profil Pemecahan Masalah Segitiga Siswa Kelas VIII SMP Negeri 19 Palu Ditinjau dari Gaya Kognitif'. 
Indriani Sira, Abd. Hamid, dan Evie Awuy, Profil Pemecahan ... 127

\section{METODE PENELITIAN}

Jenis penelitian ini adalah penelitian kualitatif. Penelitian ini dilaksanakan di kelas VIII SMP Negeri 19 Palu. Subjek yang diambil merupakan siswa yang bergaya kognitif FI dan field dependent. Dari hasil Group Embedded Figure Test (GEFT) kelompok siswa dengan gaya kognitif FD diambil satu yang mendapatkan skor terendah, jika siswa mendapatkan skor terendah yang sama maka dipilih satu subjek secara acak. Selanjutnya untuk hasil GEFT kelompok siswa dengan gaya kognitif FI juga diambil satu yang mendapatkan skor tertinggi, jika siswa mendapatkan skor tertinggi yang sama maka dipilih satu subjek secara acak. Adapun alasan mengambil skor terendah untuk FD dan skor tertinggi untuk FI bertujuan mendapatkan perbedaan data yang signifikan.

Teknik pengumpulan data pada penelitian ini adalah tes dan wawancara. Instrumen utama dalam penelitian ini adalah peneliti sendiri. Instrumen pendukung dalam penelitian ini adalah GEFT yang dikembangkan oleh Witkin (1971) dan masalah segitiga yang dibuat oleh peneliti dan telah divalidasi. Masalah segitiga yang dimaksud terdiri dari dua butir soal, masalah 1 disimbolkan M1 dan masalah 2 disimbolkan M2 seperti yang terlihat pada tabel 1 sebagai berikut:

Tabel 1. Masalah 1 (M1) dan Masalah 2 (M2)

\begin{tabular}{ll}
\hline \multicolumn{1}{c}{ Masalah (M1) } & \multicolumn{1}{c}{ Masalah 2 (M2) } \\
\hline Sebuah lapangan berbentuk segitiga, panjang & Sebuah taman berbentuk segitiga, panjang \\
sisi-sisinya $13 \mathrm{~m}, 13 \mathrm{~m}$ dan $10 \mathrm{~m}$. Jika & sisi-sisinya $15 \mathrm{~m}, 15 \mathrm{~m}$ dan 24 m. Jika \\
lapangan tersebut akan ditanami rumput & taman tersebut akan ditanami rumput \\
dengan biaya Rp. $60.000 / \mathrm{m}^{2}$, hitunglah & dengan biaya Rp. $75.000 / \mathrm{m}^{2}$, hitunglah \\
keseluruhan biaya yang diperlukan! & keseluruhan biaya yang diperlukan! \\
\hline
\end{tabular}

Uji kredibilitas data penelitian ini dilakukan dengan triangulasi waktu. Analisis data yang digunakan mengacu pada analisis data menurut Miles dan Huberman (1992) yaitu: reduksi data, penyajian data, dan penarikan kesimpulan.

\section{HASIL PENELITIAN}

Berdasarkan hasil GEFT diperoleh siswa dengan gaya kognitif FI sebanyak 9 siswa kemudian dipilih 1 siswa sebagai subjek gaya kognitif FI yaitu RN, sedangkan siswa dengan gaya kognitif FD sebanyak 10 siswa kemudian dipilih juga 1 siswa sebagai subjek gaya kognitif FD yaitu NT.

Selanjutnya setiap subjek mengerjakan M1. Untuk menguji kredibilitas data setiap subjek dalam memecahkan M1, peneliti melakukan triangulasi waktu yaitu memberikan M2 yang setara dengan M1 pada setiap subjek di waktu yang berbeda. Hasil triangulasi menunjukkan ada konsistensi jawaban subjek dalam menyelesaikan M1 dan M2, sehingga data setiap subjek dalam mengerjakan masalah segitiga dikatakan kredibel. Oleh karena data setiap subjek kredibel maka profil setiap subjek dapat menggunakan data pada M1 atau M2. Pada penelitian ini, peneliti menggunakan data setiap subjek dalam memecahkan masalah pada M2.

\section{Profil Pemecahan Masalah Segitiga Siswa FI}

Paparan data pada tahap memahami masalah. Adapun transkip wawancara subjek RN pada tahap memahami M2 sebagai berikut : 
ISM205 : iya, kalau begitu ini soalnya silahkan di baca.

RNM206 : (membaca soal secara berulang-ulang)

ISM207 : nah sudah pernah kerja soal seperti ini?

RNM208 : iya ibu. Soalnya seperti yang lalu.

ISM209 : maksudnya seperti yang lalu bagaimana?

RNM210 : seperti soal yang ibu kasih pertama cuma beda angkanya ibu.

ISM211 : oh iya, informasi apa yang didapatkan dari soal?

RNM212 : diketahui sisi-sisinya 15 meter, 15 meter dan 24 meter bu.

ISM213 : nah selain itu informasi apa lagi?

RNM214 : ini ibu diketahui juga taman berbentuk segitiga dan biaya rumput Rp. $75.000 / \mathrm{m}^{2}$.

ISM215 : selain itu ada lagi informasi lain yang didapatkan?

RNM216 : ditanyakan keseluruhan biaya yang diperlukan.

ISM219 : bagaimana rumusnya?

RNM220 : 1/2 $\mathrm{x}$ alas $\mathrm{x}$ tinggi.

ISM221 : terus diapakan lagi adik?

RNM222 : saya cari tingginya ibu pakai rumus Pythagoras karena belum diketahui.

Berdasarkan hasil transkrip wawancara di atas, dapat diketahui bahwa subjek RN dalam memahami M2 yaitu: 1) Subjek RN membaca M2 secara berulang-ulang untuk menemukan hal-hal yang diketahui dan ditanyakan (RNM206). 2) Subjek RN dapat menyebutkan informasi yang diketahui seperti: diketahui sisi-sisinya 15 meter, 15 meter dan 24 meter (RNM212), taman berbentuk segitiga dan biaya rumput Rp. $75.000 / \mathrm{m}^{2}$ (RNM214). 3) Subjek RN dapat menyebutkan informasi yang ditanyakan seperti: hitunglah keseluruhan biaya yang diperlukan (RNM216). 4) Subjek RN dapat menyebutkan informasi yang tidak diketahui seperti: tinggi segitiga (RNM222).

Tahap selanjutnya adalah membuat rencana pemecahan masalah. Adapun transkip wawancara subjek RN pada saat merencanakan pemecahan M2 sebagai berikut :

ISM217 : nah, kalau begitu bagaimana cara adik menyelesaikan soal ini?

RNM218 : macam yang lalu ibu, saya cari dulu luas taman pakai rumus segitiga.

ISM219 : bagaimana rumusnya?

RNM220 : 1/2 $\mathrm{x}$ alas $\mathrm{x}$ tinggi.

ISM221 : terus diapakan lagi adik?

RNM222 : saya cari tingginya ibu pakai rumus Pythagoras karena belum diketahui.

ISM223 : terus apa lagi dicari?

RNM224 : setelah dapat luasnya saya kalikan dengan biaya rumputnya ibu.

Berdasarkan hasil transkrip wawancara di atas, dapat diketahui bahwa subjek RN dalam membuat rencana pemecahan M2 yaitu: 1) Subjek RN akan menggunakan rumus Pythagoras untuk mencari tinggi segitiga (RNM222). 2) Subjek RN telah membuat perencanaan pemecahan M2 yang diberikan dengan cara menghitung luas taman dengan rumus luas segitiga (RNM220), mencari tinggi segitiga dengan rumus Pythagoras (RNM222) dan menghitung keseluruhan biaya rumput (RNM224).

Tahap selanjutnya adalah melaksanakan rencana pemecahan masalah. Adapun data hasil pekerjaan subjek RN tahap melaksanakan rencana penyelesaian M2 dapat dilihat sebagai berikut : 

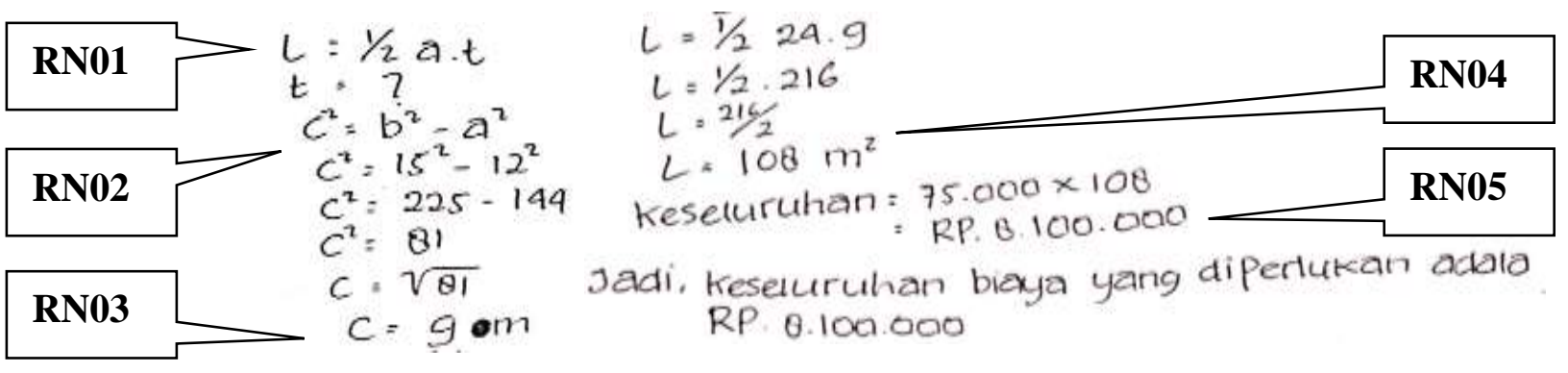

Gambar 1. Hasil Pekerjaan subjek RN

Berdasarkan hasil tes tertulis di atas, dapat diketahui bahwa subjek RN dalam melaksanakan rencana pemecahan M2 sebagai berikut: 1) Sebelum mencari luas taman (RN06), subjek RN terlebih dahulu mencari tinggi segitiga menggunakan rumus phytagoras sehingga diperoleh $9 \mathrm{~m}$. 2) Setelah itu subjek RN memasukkan nilai alas dan tinggi ke rumus luas segitiga yaitu $L=1 / 2 \times 24 \times 9$ sehingga memperoleh $L=108 \mathrm{~m}^{2}$ (RN09). 3) Untuk memperoleh keseluruhan biaya subjek RN mengalikan luas lapangan $=108 \mathrm{~m}^{2}$ dengan harga rumput Rp. 75.000,- sehingga diperoleh yaitu Rp. 8.100.000,- (RN10).

Transkrip hasil wawancara dengan subjek RN pada saat melaksanakan rencana penyelesaian M2 sebagai berikut:

ISM231 : nah disini bisa adik jelaskan cara menyelesaikan soal ini?

RNM232 : iya ibu bisa.

ISM233 : coba jelaskan bagaimana.

RNM234 : caraku sama seperti yang lalu ibu, saya cari dulu tingginya pake rumus Pythagoras.

ISM235 : terus diapakan lagi?

RNM236 : tingginya saya dapat $9 \mathrm{~m}$ ibu, terus saya masukkan di rumus, saya dapat luasnya 108 $\mathrm{m}^{2}$.

ISM237 : selanjutnya?

RNM238 : saya kali saja ibu luas yang saya dapat $108 \mathrm{~m}^{2}$ dengan harga rumput Rp. $75.000 / \mathrm{m}^{2}$. Jadi, keseluruhan biaya yang di peroleh adalah Rp. 8.100 .000

Berdasarkan hasil pekerjaan dan transkrip wawancara diatas, pada tahap ini subjek RN melaksanakan rencana pemecahan M2 sebagai berikut: 1) Sebelum mencari luas taman, subjek RN terlebih dahulu mencari tinggi segitiga menggunakan rumus Pythagoras sehingga diperoleh 9 m. 2) Setelah itu subjek RN memasukkan nilai alas dan tinggi ke rumus luas segitiga yaitu $\mathrm{L}$ $=1 / 2 \times 24 \times 9$ sehingga memperoleh $\mathrm{L}=108 \mathrm{~m}^{2}$. 3) Untuk memperoleh keseluruhan biaya subjek RN mengalikan luas lapangan $=108 \mathrm{~m}^{2}$ dengan harga rumput Rp.75.000,- sehingga diperoleh Rp. 8.100.000,-. 4) Subjek RN melaksanakan apa yang telah direncanakan sebelumnya dengan lancar.

Tahap selanjutnya adalah memeriksa kembali. Adapun data hasil wawancara subjek RN pada tahap memeriksa kembali hasil pekerjaan M2 dapat dilihat sebagai berikut :

ISM241 : yakin sudah benar jawabannya?

RNM242 : iya yakin ibu

ISM243 : bagaimana adik yakin kalo jawabannya itu sudah betul?

RNM244 : tadi sudah saya periksa ulang ibu.

ISM245 : bagaimana cara adik memeriksa ulang? Ada cara lain yang digunakan?

RNM246 : hanya saya hitung-hitung ulang ibu. 
Berdasarkan transkrip wawancara di atas, diketahui bahwa subjek $\mathrm{RN}$ dalam memeriksa kembali hasil pekerjaan M2 sebagai berikut: Subjek yakin terhadap jawabannya karena telah memeriksa ulang dan menghitungnya kembali sehingga memperoleh jawaban yang benar (RNM244 dan RNM246).

\section{Profil Pemecahan Masalah Segitiga Siswa FD}

Paparan data pada tahap memahami masalah. Adapun transkip wawancara subjek NT pada tahap memahami M2 sebagai berikut :

NTM208 : kayaknya seperti soal yang lalu bu.

ISM209 : soalnya sama persis?

NTM210 : sama ibu tapi angkanya saja yang beda

ISM211 : oh iya, informasi apa yang adik bisa dapatkan dari soal?

NTM212 : panjang sisinya ibu $15 \mathrm{~m}, 15 \mathrm{~m}$, dan $24 \mathrm{~m}$.

ISM213 : selain itu masih ada lagi?

NTM214 : ditanyakan keseluruhan biaya yang diperlukan.

ISM215 : terus ada lagi?

NTM232 : ada ibu, tamannya berbentuk segitiga dan biaya rumputnya Rp.75.000/m²

Berdasarkan hasil transkip wawancara di atas, dapat diketahui bahwa subjek NT dalam memahami M2 yaitu: 1) Subjek NT juga membaca soal berulang ulang untuk memahami informasi yang ditanyakan seperti: hitunglah keseluruhan biaya yang diperlukan (NTM214). 2) Subjek NT membaca soal berulang-ulang untuk memahami informasi yang diketahui seperti: sisi-sisinya 15 meter, 15 meter dan 24 meter (NTM212), tamannya berbentuk segitiga dan biaya rumputnya Rp. 75.000/ $\mathrm{m}^{2}$ (NTM232).

Tahap selanjutnya adalah membuat rencana pemecahan masalah. Adapun transkip wawancara subjek NT pada saat merencanakan pemecahan M2 sebagai berikut :

ISM217 : nah, kalau begitu bagaimana cara adik menyelesaikan soal ini?

NTM218 : saya langsung cari luas tamannya ibu pake rumus luas segitiga.

ISM219 : terus diapakan lagi?

NTM220 : luas tamannya ibu saya kali dengan harga rumputnya.

ISM221 : selanjutnya bagaimana?

NTM222 : itu sudah hasilnya.

Berdasarkan hasil transkip wawancara di atas, dapat diketahui bahwa subjek NT dalam membuat rencana pemecahan M2 yaitu: 1) Pertama subjek NT merencanakan mencari luas taman yang berbentuk segitiga (NTM218 dan NTM220). Kemudian mengalikan luas taman dan harga rumput untuk mendapatkan biaya keseluruhan. 2) Subjek NT tidak menyadari bahwa tinggi segitiga belum diketahui.

Adapun data hasil pekerjaan subjek NT tahap melaksanakan rencana penyelesaian M2 dapat dilihat sebagai berikut : 


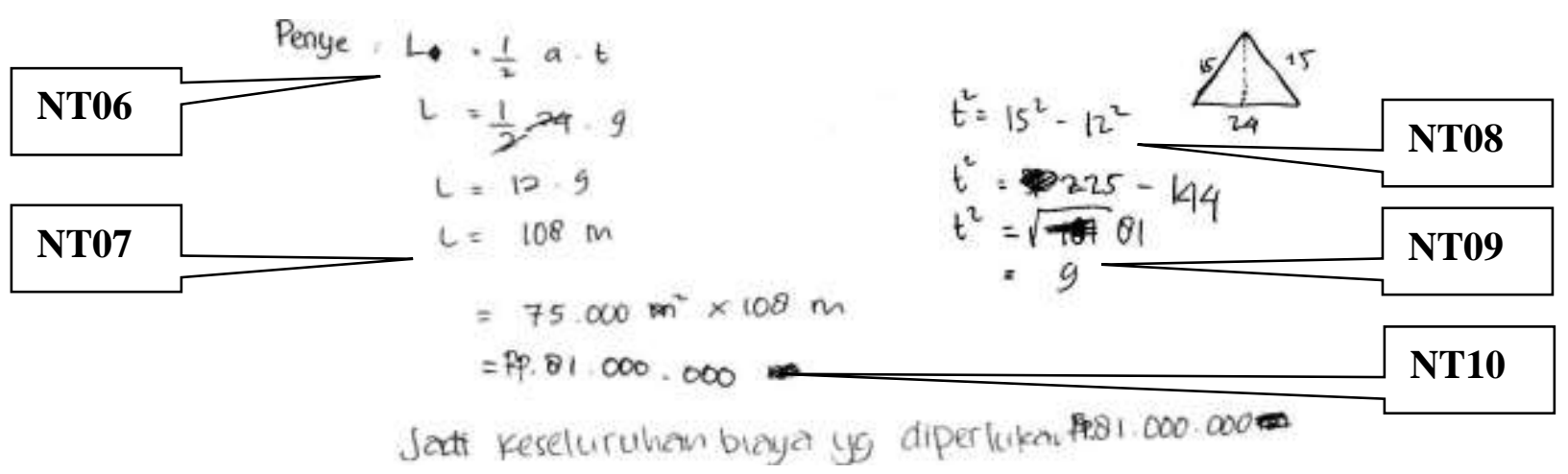

Gambar 2. Hasil Pekerjaan subjek NT

Berdasarkan hasil tes tertulis di atas, dapat diketahui bahwa subjek NT dalam melaksanakan rencana pemecahan M2 sebagai berikut: 1) Sebelum menghitung luas taman subjek NT menyadari tinggi segitiga belum diketahui sehingga terlebih dahulu mencari menggunakan rumus Pythagoras sehingga diperoleh $9 \mathrm{~m}$, terlihat juga subjek masih keliru dalam menggunakan rumus Pythagoras (NT08 dan NT09). 2) Setelah itu subjek NT mensubtitusi nilai alas dan tinggi ke rumus luas segitiga yaitu $L=1 / 2 \times 24 \times 9, L=12 \times 9$ sehingga $\mathrm{L}=108 \mathrm{~m}^{2}$. (NT06 dan NT07). 3) Selanjutnya subjek NT mengalikan luas lapangan = $108 \mathrm{~m}^{2}$ dengan harga rumput Rp. 75.000,- sehingga diperoleh yaitu Rp. 81.000.000,-, di sini subjek NT kurang teliti dalam melakukan operasi perkalian seharusnya hasil yang diperoleh Rp. 8.100.000,- (NT10).

Transkip hasil wawancara dengan subjek NT pada saat melaksanakan rencana penyelesaian M2 sebagai berikut:

NTM234 : saya cari dulu tingginya ibu, karena belum diketahui.

ISM235 : diapakan lagi habis itu?

NTM236 : baru saya masukkan semua nilainya di rumus luas segitiga ibu.

ISM237 : terus bagaimana?

NTM238 : luasnya saya kali dengan harga rumput, hasilnya Rp. 81.000.000

ISM239 : oh iya adik, tapi adik sudah yakin dengan hasilnya?

NTM240 : oh iya ibu harusnya Rp 8.100.000.

Berdasarkan hasil pekerjaan dan transkrip wawancara di atas, pada tahap ini subjek NT melaksanakan rencana pemecahan M2 sebagai berikut: 1) Sebelum menghitung luas taman subjek NT menyadari tinggi segitiga belum diketahui sehingga terlebih dahulu mencari menggunakan rumus Pythagoras sehingga diperoleh $9 \mathrm{~m}$, terlihat juga subjek masih keliru dalam menggunakan rumus Pythagoras. 2) Setelah itu subjek NT mensubtitusi nilai alas dan tinggi ke rumus luas segitiga yaitu $\mathrm{L}=1 / 2 \times 24 \times 9, \mathrm{~L}=12 \times 9$ sehingga $\mathrm{L}=108 \mathrm{~m}^{2}$. 3) Selanjutnya subjek NT mengalikan luas lapangan $=108 \mathrm{~m}^{2}$ dengan harga rumput Rp. 75.000,- sehingga diperoleh yaitu Rp. 81.000.000,-, di sini subjek NT kurang teliti dalam melakukan operasi perkalian. 4) Terlihat subjek NT masih keliru dalam mengerjakan M2 dan subjek NT mengerjakan M2 tidak sesuai strategi yang dibuat sebelumnya dikarenakan subjek baru menyadari nilai tinggi dari segitiga belum diketahui.

Tahap selanjutnya adalah memeriksa kembali. Adapun data hasil wawancara subjek NT pada tahap memeriksa kembali hasil pekerjaan M2 dapat dilihat sebagai berikut :

ISM241 : sudah selesai sampai di situ adik?

NTM242 : iya ibu.

ISM243 : yakin sudah benar jawabannya? 
NTM244 : iya ibu begitu sudah.

ISM245 : oh iya, kalo begitu terima kasih atas waktunya.

NTM246 : iya ibu sama-sama.

Berdasarkan transkrip wawancara di atas, diketahui bahwa subjek NT dalam memeriksa kembali hasil pekerjaan M2 sebagai berikut: Subjek NT tidak memeriksa kembali hasil pekerjaan (NTM244), dapat di lihat juga subjek NT keliru saat mencari keseluruhan biaya yang diperlukan yaitu Rp.81.000.000,- seharusnya hasilnya Rp.8.100.000,-.

\section{PEMBAHASAN}

Berdasarkan hasil penelitian, diperoleh bahwa pada tahap memahami masalah subjek yang memiliki gaya kognitif FI tidak langsung dapat memahami masalah yang diberikan. Subjek FI memahami masalah dengan cara membaca masalah berulang-ulang. Hal ini seperti pendapat yang dikemukakan oleh Hudojo (Arfanuddin, 2016) bahwa masalah adalah suatu soal yang ingin dipecahkan oleh seseorang (termasuk siswa), tetapi cara/langkah untuk memecahkannya tidak segera ditemukan orang itu.

Selanjutnya setelah subjek FI dapat memahami masalah, subjek dapat menyebutkan informasi yang diketahui dan ditanyakan. Hal ini sesuai dengan pendapat yang diungkapkan oleh Sudarman (2011) yang menyatakan bahwa dalam memahami masalah siswa dapat mengidentifikasi yang diketahui dengan melihat kalimat pernyataan pada masalah yang diberikan, dan yang ditanyakan dengan melihat kalimat tanya atau perintah pada masalah yang diberikan.

Berdasarkan uraian di atas dapat disimpulkan bahwa untuk memahami masalah subjek yang memiliki gaya kognitif FI dengan cara membaca masalah berulang-ulang, setelah membaca masalah berulang-ulang barulah subjek dapat mengidentifikasi informasi-informasi yang diketahui dan ditanyakan.

Subjek yang memiliki gaya kognitif FI mempunyai rencana pemecahan masalah dengan cara menghitung luas taman menggunakan rumus luas segitiga dan untuk mencari tinggi segitiga dengan rumus Pythagoras. Hal ini sesuai dengan pendapat yang dikemukakan oleh Hudojo (Aldino, 2016) bahwa untuk menyelesaikan masalah orang harus menguasai hal-hal yang telah dipelajari sebelumnya dan menggunakannya di dalam situasi yang baru.

Selanjutnya subjek FI dapat menjelaskan perencanaan pemecahan masalah yang diberikan dengan baik. Hal tersebut ditunjukkan dengan kemampuan membuat hubungan antara informasi yang ada dengan masalah yang ditanyakan yaitu membuat hubungan antara luas taman dengan biaya keseluruhan untuk ditanami rumput. Hal ini sesuai dengan yang dikemukakan oleh Polya (Yuwono, 2010) pada tahap membuat rencana pemecahan siswa mencari hubungan antara informasi yang diberikan dengan yang tidak diketahui dan memungkinkan untuk dihitung variabel yang tidak diketahui tersebut.

Berdasarkan uraian di atas, dapat disimpulkan bahwa subjek dengan gaya kognitif FI pada tahap membuat rencana penyelesaian adalah mampu membuat hubungan antara informasi yang ada dengan masalah yang ditanyakan dengan mengaitkan pengetahuan dan pengalaman yang telah dipelajari sebelumnya, sehingga mampu membuat perencanaan pemecahan masalah yang diberikan dengan baik.

Pemecahan masalah subjek dengan yang memiliki gaya kognitif FI pada tahap melaksanakan rencana pemecahan masalah dengan cara menghubungkan informasi yang diperoleh pada tahap memahami masalah dengan rencana yang telah dibuat, selanjutnya melaksanakan rencana yang telah dibuat tersebut dengan terlebih dahulu mencari informasi yang belum diketahui, informasi yang diperoleh di substitusi ke rumus luas segitiga untuk memperoleh biaya keseluruhan. Hal ini sesuai dengan pendapat yang dikemukakan oleh Arfanuddin (2016) 
saat melaksanakan rencana penyelesaian masalah, subjek FI secara langsung dapat menerapkan ide-idenya untuk menyelesaikan masalah dengan melaksanakan rencana sesuai apa yang direncanakan. FI fokus memproses dan menganalisis hubungan bagian masalah yang dicari hingga menemukan hasil yang dicari.

Pada proses pengerjaan, subjek FI menguasai konsep yang telah dipelajari sebelumnya yaitu menguasai konsep bangun datar khususnya segitiga dan teorema Pythagoras sehingga memperoleh hasil yang benar. Seperti yang dikemukakan oleh Thobroni dan Mustofa (2011) bahwa belajar dihasilkan dari proses mengorganisikan kembali persepsi dan membentuk keterhubungan antara pengalaman yang baru dialami seseorang dan apa yang sudah tersimpan di dalam benaknya.

Berdasarkan uraian diatas, dapat disimpulkan bahwa dalam melaksanakan rencana pemecahan masalah, subjek dengan gaya kognitif FI dapat menerapkan rencana yang telah dibuat selanjutnya melaksanakan rencana dengan menggunakan konsep yang telah dipelajari sebelumnya.

Tahap ini merupakan langkah terakhir dalam pemecahan masalah menurut Polya. Subjek yang memiliki gaya kognitif FI yakin terhadap jawabannya karena telah memeriksa ulang dan menghitungnya kembali sehingga memperoleh jawaban yang benar. Hal ini sesuai dengan pendapat yang dikemukakan oleh Azizah (2016) dalam tahap memeriksa kembali, subjek mengolah informasi dengan mengecek kembali hasil pengerjaannya. Subjek memanggil kembali informasi dengan mengkoreksi kembali hasil pengerjaan lalu mengatakan bahwa ia sudah yakin dengan jawabannya dan hasil yang ia dapatkan sudah sesuai dengan tujuan yang ingin dicapai.

Berdasarkan uraian di atas dapat disimpulkan pemecahan masalah subjek yang memiliki gaya kognitif FI pada tahap memeriksa kembali hasil pekerjaan adalah subjek memeriksa kembali langkah demi langkah hasil pekerjaan dan meyakini kebenaran jawabannya dengan melakukan perhitungan kembali.

Pada tahap memahami masalah subjek yang memiliki gaya kognitif FD tidak langsung dapat memahami masalah yang diberikan. Subjek FD dalam memahami masalah dengan cara membaca masalah berulang-ulang dan membutuhkan waktu yang lebih lama. Hal ini juga sesuai dengan pendapat yang diungkapkan oleh Polya (1973) bahwa siswa harus melihat dengan jelas apa saja yang diperlukan dalam memahami masalah dengan baik. Sehingga dari informasi-informasi yang ada, sudah cukup untuk digunakan dalam menjawab masalah yang diberikan.

Setelah subjek FD membutuhkan waktu yang lebih lama untuk dapat memahami masalah, selanjutnya subjek mampu memahami informasi yang diketahui dan ditanyakan. Hal ini sejalan dengan pendapat Yuwono (2010) yang menyatakan bahwa dalam memahami masalah siswa dapat menentukan hal-hal yang diketahui dan hal-hal yang ditanyakan.

Berdasarkan uraian di atas dapat disimpulkan bahwa untuk memahami masalah subjek yang memiliki gaya kognitif FD dengan cara membaca masalah berulang-ulang dan membutuhkan waktu yang lebih lama dalam memahami masalah.

Subjek FD menjelaskan perencanaan pemecahan masalah yang diberikan masih keliru karena subjek tidak mencari nilai tinggi yang belum diketahui menggunakan rumus Pythagoras. Hal ini sesuai dengan yang dikemukakan oleh Azizah (2016) bahwa subjek mengolah informasi dengan menceritakan perencanaan masalah yang dilakukan secara runtut tetapi dengan menggunakan perencanaan yang kurang tepat sehingga dapat diketahui bahwa subjek FD masih belum memahami konsep materi sebelumnya.

Berdasarkan uraian di atas, dapat disimpulkan bahwa subjek dengan gaya kognitif FD kurang tepat dalam membuat rencana penyelesaian . 
Pemecahan masalah subjek dengan yang memiliki gaya kognitif FD pada tahap melaksanakan rencana pemecahan masalah terlihat subjek tidak menyelesaikan masalah sesuai rencana yang dibuat sebelumnya, subjek menambahkan beberapa strategi untuk dapat menyelesaikan masalah yang dihadapi. Hal ini sesuai dengan pendapat yang dikemukakan oleh Hudojo (Arfanuddin, 2016) bahwa sebuah perencanaan, memahami ide solusi tidak menjadi jaminan untuk mudah berhasil menyelesaikan masalah, diperlukan pengetahuan prasyarat yang baik. Hal ini sesuai dengan pendapat yang dikemukakan oleh Wijaya (Arfanuddin, 2016) dengan karakteristik gaya kognitif FD yang kesulitan memproses informasi dan cenderung hanya menerima informasi yang disajikan tanpa mengorganisasi kembali.

Berdasarkan uraian diatas, dapat disimpulkan bahwa dalam melaksanakan rencana pemecahan masalah subjek dengan gaya kognitif FD mengalami kesulitan dalam menerapkan rencana yang telah dibuat sebelumnya sehingga menambahkan beberapa strategi untuk dapat menyelesaikan masalah yang dihadapi.

Pada tahap memeriksa kembali hasil pekerjaan, Subjek yang memiliki gaya kognitif FD tidak mengecek kembali hasil pekerjaan sehingga keliru pada hasil akhir. Hal ini sesuai dengan pendapat yang dikemukakan oleh Azizah (2016) bahwa dalam tahap memeriksa kembali, subjek FD tidak memeriksa kembali hasil pengerjaannya karena sudah merasa yakin dengan jawabannya. Karena subjek tidak memeriksa kembali jawabannya, subjek tidak sadar akan kesalahannya dalam mengerjakan.

Berdasarkan uraian di atas dapat disimpulkan pemecahan masalah subjek yang memiliki gaya kognitif FD pada tahap memeriksa kembali hasil pekerjaan adalah subjek tidak melakukan pengecekan kembali hasil pekerjaan sehingga tidak menyadari kesalahan dalam mengerjakan.

\section{KESIMPULAN}

Berdasarkan hasil penelitian dan pembahasan, maka dapat disimpulkan bahwa: Profil pemecahan masalah siswa dengan gaya kognitif FI dan FD dalam pemecahan masalah segitiga adalah sebagai berikut: 1) Profil pemecahan masalah siswa FI pada tahap memahami masalah yaitu: dengan cara membaca masalah berulang-ulang, setelah membaca masalah berulangulang barulah subjek dapat mengidentifikasi informasi-informasi yang diketahui dan ditanyakan, sedangkan profil pemecahan masalah siswa FD pada tahap memahami masalah yaitu: subjek yang memiliki gaya kognitif FD untuk memahami masalah dengan cara membaca masalah berulang-ulang dan membutuhkan waktu yang lebih lama dalam memahami masalah. 2) Profil pemecahan masalah siswa FI pada tahap membuat rencana pemecahan masalah yaitu: mampu membuat hubungan antara informasi yang ada dengan masalah yang ditanyakan dengan mengaitkan pengetahuan dan pengalaman yang telah dipelajari sebelumnya, sehingga mampu membuat perencanaan pemecahan masalah yang diberikan dengan baik, sedangkan profil pemecahan masalah siswa FD pada tahap membuat rencana pemecahan masalah yaitu: subjek kurang tepat dalam membuat rencana. 3) Profil pemecahan masalah subjek FI pada tahap melaksanakan rencana pemecahan masalah yaitu subjek dapat menerapkan rencana yang telah dibuat, selanjutnya melaksanakan rencana dengan menggunakan konsep yang telah dipelajari sebelumnya, sedangkan profil pemecahan masalah subjek FD pada tahap melaksanakan rencana pemecahan masalah yaitu subjek mengalami kesulitan dalam menerapkan rencana yang telah dibuat sebelumnya sehingga menambahkan beberapa strategi untuk dapat menyelesaikan masalah yang dihadapi. 4) Profil pemecahan masalah siswa FI pada tahap memeriksa kembali yaitu: subjek memeriksa kembali langkah demi langkah hasil pekerjaan dan meyakini kebenaran jawabannya dengan melakukan perhitungan kembali, sedangkan profil pemecahan masalah siswa FD pada tahap memeriksa kembali yaitu: subjek 
tidak melakukan pengecekan kembali hasil pekerjaan sehingga tidak menyadari kesalahan dalam mengerjakan.

\section{SARAN}

Berdasarkan hasil penelitian dan pembahasan yang telah dikemukakan, maka peneliti menyarankan kepada guru maupun calon guru agar pada saat melaksanakan pembelajaran sebaiknya perlu memperhatikan hal-hal berikut: 1) Gaya kognitif FI dan FD sangat mempengaruhi pemecahan masalah siswa dalam belajar matematika, sehingga guru perlu memperhatikan kondisi tersebut dalam kegiatan pembelajaran di kelas. Perhatian guru terhadap siswa yang memiliki gaya kognitif FI dan FD tentunya akan berimplikasi pada pemilihan strategi pembelajaran yang sesuai sehingga dapat memberikan hasil belajar yang positif bagi siswa dengan gaya kognitif FI dan FD. 2) Hasil penelitian ini dapat dijadikan sebagai salah satu bahan informasi untuk membuat penelitian yang lebih luas tentang profil pemecahan masalah siswa FI dan FD dengan materi yang berbeda.

\section{DAFTAR PUSTAKA}

Abidin, Z. (2015). Intuisi Dalam Pembelajaran Matematika. Jakarta: Lentera ilmu Cendikia.

Aldino, F (2016). Profil Siswa Auditorial Pada Kelas X SMA Dalam Memecahkan Masalah Sistem Persamaan Linear Dua Variabel Ditinjau dari Perbedaan Gender. Skripsi tidak diterbitkan. Palu: Universitas Tadulako.

Arfanuddin (2016). Profil Pemecahan Masalah Matematika Siswa SMK Kelas X Ditinjau dari

GayaKognitif.[Online].Tersedia:http://jurnal.untad.ac.id/jurnal/index.php/AKSIOMA/ article/view/8647/6867 [10 September 2017]

Azizah, B. (2016). Profil Pemecahan Masalah Matematika Anak Autis Ditinjau dari Gaya Kognitif FD dan Field Independent. [Online]. Tersedia: http://digilib. uinsby.ac.id/11946/2 /Abstrak.pdf. [09 Januari 2017].

Depdiknas. (2006). Kurikulum Tingkat Satuan Pendidikan (KTSP) 2006 mata pelajaran matematika. Jakarta: Departemen Pendidikan Nasional.

Hudojo, H. (2009). Belajar dan Mengajar Matematika. Malang: IKIP Malang.

Miles, M. B. dan Huberman, A.M. (1992). Analaisis Data Kualitatif: Buku Sumber Metode Baru. Terjemahan oleh: Tjetjep Rohendi Rohedi. Jakarta: UI Press.

Polya, G. (1973). How To Solve It (New of Mathematical Method).Second Edition. New Jersey: Princeton University press.

Slameto. (2003). Belajar dan Faktor-Faktor Yang Mempengaruhinya. Jakarta: Rineke Cipta

Sudarman. (2011). Proses Berpikir Siswa Quitter pada Sekolah Menengah Pertama dalam Menyelesaikan Masalah Matematika. Jurnal Pendidikan Matematika (Edumatica). Vol. 01 No.2. 15-24. 
Thobroni, M dan Mustofa, A. (2011). Belajar dan Pembelejaran Pengembangan Wacana dan Praktek Pembelajaran dalam Pembangunan Nasional. Jogjakarta: Ar-Ruzz Media.

Wisman, (2016). Profil Pemecahan Masalah Siswa FD Kelas X SMA Negeri Model Terpadu Madani Pada Materi Relasi dan Fungsi. Skripsi tidak diterbitkan. Palu: Universitas Tadulako.

Witkin, H.A. (1971). Cognitive Style In Academic Performance And Teacher-Student Relations. San Francisco: Jossey-Bass.

Yuwono, A. (2010). Profil Siswa SMA Dalam Memecahkan Masalah Matematika Ditinjau dari Tipe Kepribadian. Thesis.[Online].Tersedia: http://eprints.uns.ac.id/7294/1/131 790608201 008281.pdf, [09 Januari 2017]. 